\title{
RARE ELEMENTS DISTRIBUTION AND MINERALIZATION POTENTIALITY OF PEGMATITES IN GABAL ABU SAMYUK GRANITE, NORTH EASTERN DESERT, EGYPT
}

\author{
Ahmed Ali Abu Steet, Hassan Ismail El Sundoly, Amr Abdel Aty Abdel Hamid \\ Nuclear Materials Authority, P.O. 530 El-Maadi, Cairo, Egypt
}

\begin{abstract}
Numerous pegmatite bodies are hosted by Gabal Abu Samyuk perthitic granite, which constituting part of the Late Neoproterozoic Gattar granites in the North Eastern Desert of Egypt. The pegmatite bodies have in most cases lenticular and irregular outlines within the host granite. They range in size from few meters to $25 \mathrm{~m}$ length and their width usually less than $7 \mathrm{~m}$, although small pockets are also present. Most of the pegmatites display simple zoning structure that consists of feldspar-rich outer zone and internal quartz core. The gamma-ray measurements over these pegmatites indicated that some bodies are radiometrically anomalous, dominantly in the feldspar-rich outer zones. The radioactive zones were sampled with the aim to study the mineralogical compositions, distribution of trace elements and assessment of the mineralization potentiality of these pegmatites. The mineralogical data of the mineral separates revealed that the rare metals primarily comprised zircon, fergusonite- $(\mathrm{Y})$, columbite- $(\mathrm{Fe})$ and xenotime-(Y). Trace and rare earth elements are extremely variable with different degrees of enrichment in $\mathrm{Zr}, \mathrm{Th}, \mathrm{U}, \mathrm{Nb}, \mathrm{Ta}, \mathrm{Y}$ and REE. The studied pegmatites show a NYF-type mineralogical and geochemical signature, whereas the enrichment of rare element can be explained by high degrees of fractional crystallization of a suite of volatile-rich magmas.
\end{abstract}

Keywords: Rare metal pegmatites, Radioactivity, Zircon, Gattar granites

\section{INTRODUCTION}

Rare element pegmatites are well recognized for the diversity and concentrations of metal ores that they host. The classifications of granitic pegmatites, particularly those enriched in rare metals, have been described by Ĉerny and Ecrit (2005). An important class of rare element pegmatites is the complex-type pegmatites of the NYF (Nb-Y-F) family (Ĉerny and Ercit 2005; Ĉerny et al. 2012). This type of pegmatites is enriched in $\mathrm{Nb}, \mathrm{Y}$, and $\mathrm{F} \pm \mathrm{Be}, \mathrm{REE}, \mathrm{Sc}, \mathrm{Ti}, \mathrm{Zr}, \mathrm{Th}$, and $\mathrm{U}$. They are commonly derived from A-type and I-type granites (Ĉerny and Ecrit, 2005). Rare-element pegmatites belonging to the NYF class, together with numerous outcrops of younger granites are common in the Precambrian basement complex of Egypt, particularly in the northern domain of the Eastern Desert (e.g. Wadi Dara: Shalaby 1985; Ali 2007, Gabal Abu Khashaba: Nossiar 1987, Wadi Hawashia: Mohamed et al. 1994, Gabal El Urf: Asran et al. 2013).The rare metal pegmatites appear usually as intrusive bodies hosted by granitic rocks, which representing a complete in situ sequence from granites to highly evolved pegmatites. The host granites are post-orogenic to anorogenic younger granites, which themselves constitute a target for rare metal exploration in Egypt.

Gabal (G.) Abu Samyuk is a central granite pluton of the Late Neoproterozoic Gattar granites. The Gattar granites, North Eastern Desert of Egypt, have been investigated for uranium by the Nuclear Materials Authority of Egypt with exploration program began on 1987's. The area hosts historical Mo mineralization besides $\mathrm{U}-\mathrm{Th} \pm \mathrm{REE}$ showings in the northern district of the batholith. The southern granitic plutons, included Gabal Abu Samyuk granite, have been studied by many researchers (e.g. Ayoub, 1997; El Sundoly, 2008; El Dabe, 2010). They have been presented radiometric data of Abu Samyuk granite and associated pegmatites, which emphasizing radioactive anomalies within the pegmatites. In this contribution, we shed more light on the mineralogical compositions and geochemical characteristics of these radioactive pegmatites as well as evaluating their mineralization potentiality. 


\section{REGIONAL GEOLOGY}

The late stage of Neoproterozoic crustal evolution in Egypt is characterized by the intrusion of a group of granitic rocks known as the younger granites (Akaad and Noweir 1980; EI Gaby et al. 1988, 1990). The younger granites constitute approximately $30 \%$ of plutonic assemblages in the Eastern Desert, which are widely scattered in the northern part (Hassan and Hashad 1990). These granites mainly occur as circular massifs emplaced as discordant bodies at shallow crustal levels from about 610 to $550 \mathrm{Ma}$ (Beyth et al., 1994; Furnes et al., 1996; El-Sayed, 1998; Moghazi, 1999). They are post-orogenic to anorogenic and consist of alkali granite, syenogranite, and monzogranite associations (Hassan and Hashad 1990; Stern and Gottfried 1986; Beyth et al. 1994). They have been further classified into I- and A-types based on their geochemical characteristics (e.g., Hussein et al. 1982; El Gaby et al. 1990; Noweir et al. 1990).

Abu Samyuk granite is a part of Gattar younger granites that situated in the high mountainous area of the North Eastern Desert of Egypt, about 35km to the west of Hurghada city from the Red Sea coast (Fig. 1a). The Gattar granites are typical Late Pan- African younger granites in the Arabian-Nubian Shield. It was formed in the last stage of the Shield evolution from about 604.8 $\pm 3.3 \mathrm{Ma}$ (Moussa et al., 2008). The Gattar batholith is roughly oval-shaped, with $\mathrm{N}-\mathrm{S}$ orientation, and occupies an area of $450 \mathrm{~km}^{2}$. It forms mountainous terrains including G. Gattar, G. Um Dissi, G. Kehla, G. Abu El Hassan, G. Abu Samyuk and G. Ain Ruyashed (Fig. 1b). These plutons are classified according to modal mineralogical compositions into monzogranite, syenogranite and alkali feldspar granites (Ayoub, 1997; Atia et al. 1998; El Sayed et al. 2003; El Dabe, 2010; Mahdy et al. 2015).Country rocks include metavolcanics, arc granitoids (older granitoids) and Hammamat sedimentary rocks (molasses-type sediments).

The Gattar younger granites intrude metavolcanics that represented by ENE-WSW trending roof pendants extending over the center of the batholith along Wadi (W.) Thelma (Fig. 1b). The metavolcanics are composed of metabasalts and metadolerites with some agglomerate and tuff intercalations. Older granitoids are represented by diorite, quartz diorite and granodiorite at the southeastern part of the batholith. Hammamat sedimentary rocks of molasses-type are occurring at the northern peripheries of the batholith. They are mainly composed of polymictic conglomerates at the base while greywackes and siltstones occur upwards (Roz 1994; Abu Zeid 1995).

\section{GEOLOGY, PETROGRAPHY AND GEOCHEMISTRY OF ABU SAMYUK GRANITE}

The area of Gabal Abu Samyuk is covered mainly by perthitic granite (alkaline syenogranite) and metavolcanics (Fig. 1c). Abu Samyuk granite forms relatively small rounded to subrounded body of high relief with clear intrusive contacts with the metavolcanics. The metavolcanics are represented by scattered isolated outcrops, which occurring as roof pendants over Abu Samyuk granite. The granite cut by one or more sets of faults that cause a very distinctive rugged topography. This granite is intensely crossed by dike swarms, which are mainly of basic composition and extend for several kilometers mainly to the NE-SW direction. It is characterized by abundant aplites, quartz veins and pegmatites.

The granite is medium-grained, leucocratic of pink to pale red color. It is made up principally of perthite and quartz with minor plagioclase and shows equigranular hypidiomorphic texture. The accessory minerals are biotite, zircon, allanite and iron oxides. Allanite and zircon are highly abundant in this granite and constitute the major radioactive minerals. Plagioclase is weakly sericitized with local zoning. Micas are relatively fresh with weak chloritization. Quartz intergrowth with albite and microcline, along with a graphic texture, are observed in some cases. The granite is classified according to modal composition into syenogranite (Ayoub 1997; El Dabe 2010).

Geochemically, this granite is metaluminous with slightly peraluminous affinity. It is originated from alkaline to subalkaline magma in post-orogenic environment. It is characterized by elevated contents of $\mathrm{SiO}_{2}$ and alkalis, low abundances of $\mathrm{MgO}, \mathrm{TiO}_{2}$ and $\mathrm{CaO}$, and $\mathrm{P}_{2} \mathrm{O}_{5}$. The trace elements show negative anomaly in $\mathrm{Ba}, \mathrm{Sr}, \mathrm{P}, \mathrm{Ti}, \mathrm{Nb}$ and positive anomaly in $\mathrm{Pb}, \mathrm{Zr}, \mathrm{U}$ and $\mathrm{Th}$. The $\Sigma \mathrm{REE}$ average is $250 \mathrm{ppm}$ and characterized by negative Eu anomaly (El Sayed et al. 2003; El Dabe 2010; Mahdy et al. 2015). 
Fig. 1: (a) Landsat google earth image showing the location of Gattar granites, (b) Geologic map of Gattar area showing the mountainous terrains of $\mathrm{G}$. Abu Samyuk, G. Gattar, G. Um Dissi, G. Kehla, G. Abu El Hassan and G. Ain Ruyashed (modified after El Rakaiby and Shalaby 1988; Ayoub, 1997; El Sundoly 2008; El Dabe 2010; Mahdy et al. 2015) and (c) Geologic map of G. Abu Samyuk suite showing the locations of the radioactive pegmatites.

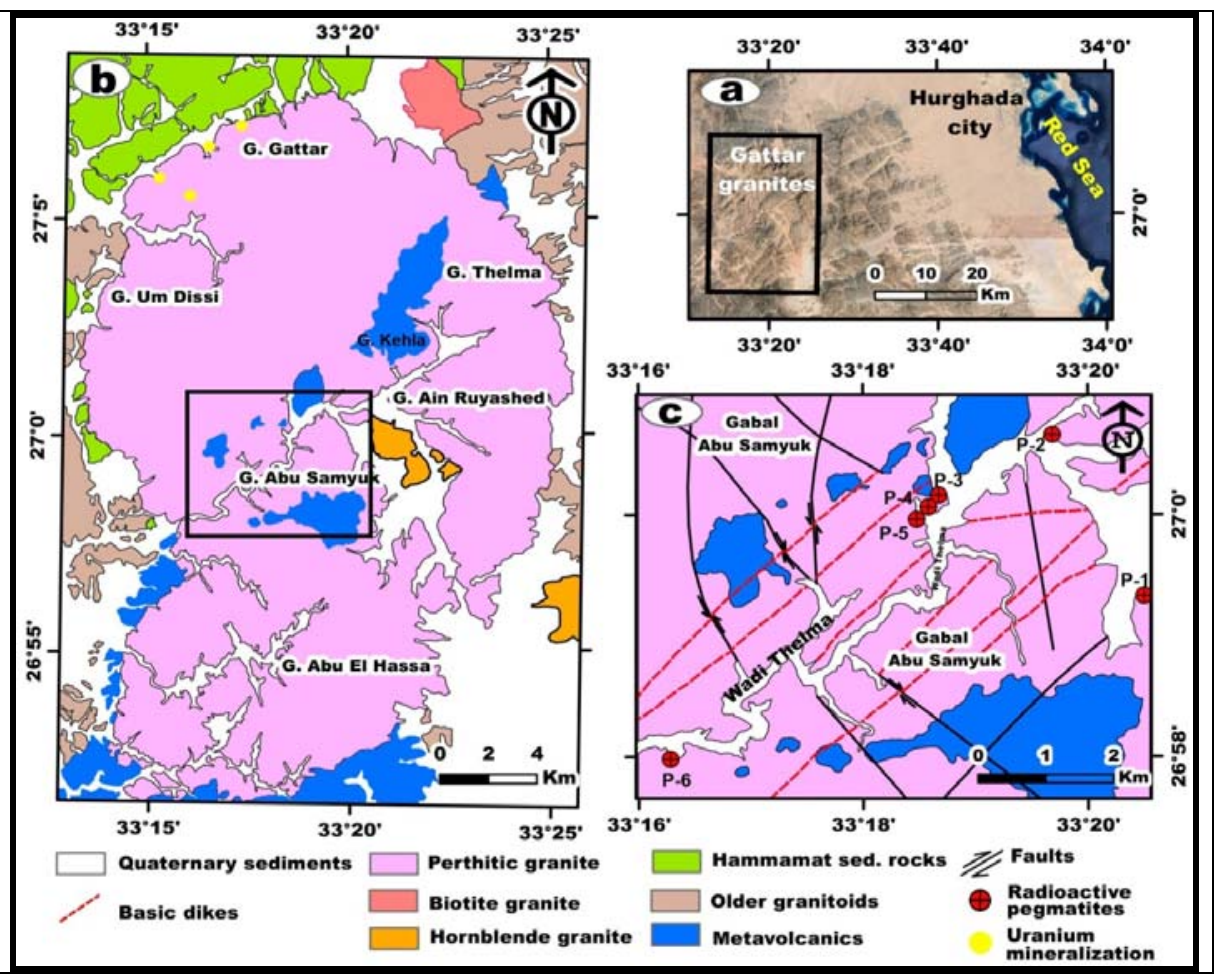

\section{Description of the pegmatites}

Numerous pegmatite bodies occur in association with aplites and quartz veins at the marginal parts of G. Abu Samyuk granite as well as along fault zones or at the contacts with the metavolcanics. The sizes of the pegmatites are ranging from small pockets to large bodies, exhibiting lenticular and irregular shapes in the host granite. The large bodies reach $25 \mathrm{~m}$ length and $7 \mathrm{~m}$ width (Fig. 2a). Most of these pegmatites have simple zoned structure, typically comprising a feldspar-rich outer zone and inner quartz core. In some reason, pockets of quartz or iron oxides are scattered along the outer zone. They were radiometrically surveyed using a portable gamma ray scintillometer detector, model RS-230, that measures the total gamma activity in count per second (cps). Six radioactive pegmatite bodies were documented along the peripheries of Abu Samyuk granite through W. Thelma. They display elevated values of gamma-ray measurements relative to the host granite. The locations of the radioactive pegmatite are delineated in the geological map and labeled as P-1, P-2,...to P-6. The highest spots occur in the microfractures of the pegmatites, generally associated with weak wall-rock alteration features. There is no signs of hydrothermal overprint and all the alterations features are products of surficial weathering. The highest gamma intensities are varying between 1300 and $3300 \mathrm{cps}$ with spots reach $20000 \mathrm{cps}$ in P-2 body. The radioactive zones exist in the feldspar-rich outer zone of the pegmatites, except one body (P-2) of which the highest radiations are emanated from a Fe-rich pocket (Fig. 2b). The Fe-rich pockets are usually noticed in all pegmatites, revealed that these rocks have the same mineralogical composition of the host granite with K-feldspar, quartz and the main accessory mineral iron oxides. The associations of these minerals indicated that the pegmatite itself represents a product of crystallization of a residual liquid issued from parent magma with a composition similar to the host Abu Samyuk granite.

\section{Sampling methods and analytical techniques}

Six bulk samples were collected from the radioactive zones along the studied pegmatites. They include five samples from the feldspar-rich zones and one sample from the radioactive Fe-rich pocket. Thin sections were prepared to identify the main rock-forming minerals and their textures. Heavy minerals were separated from low-density minerals through the standard heavy liquid method, using bromoform (SG 
2.89), then washed, dried and studied under the binocular microscope. SEM image and semi-quantitative analyses (EDS) of the picked mineral grains were identified by a Phillips XL 30 Scanning Electron microscope at the laboratory of the Nuclear Materials Authority of Egypt. Major and trace element concentrations of whole rock samples were determined by inductively coupled plasma-mass spectrometry (ICP-MS) at the ACME Analytical Laboratory, Vancouver, Canada.

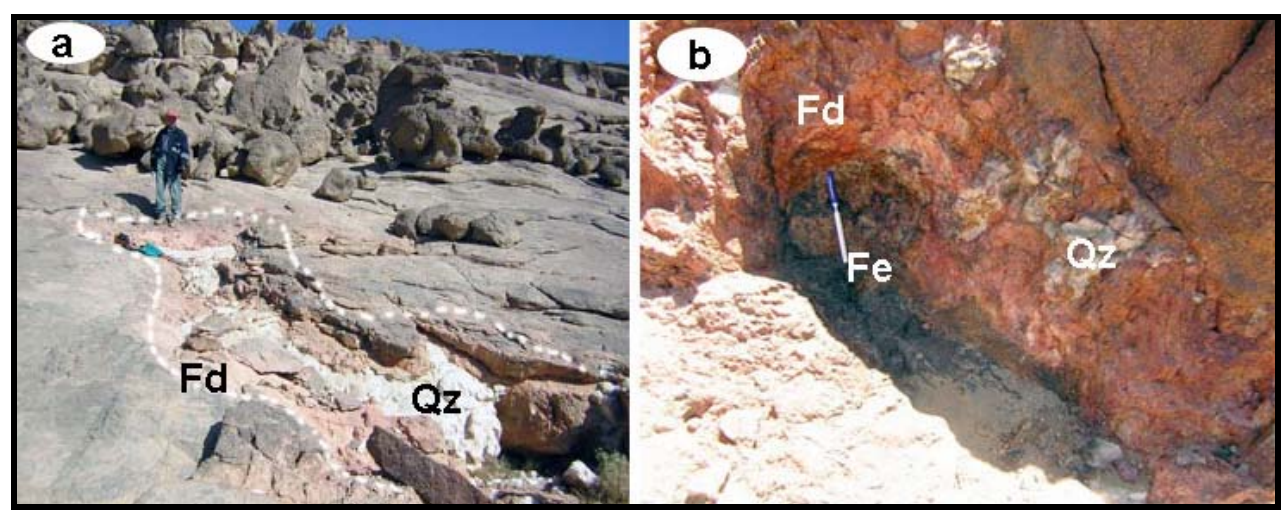

Fig. 2: (a) Zoned pegmatite body in the host G. Abu Samyuk granite and (b) Radioactive Fe-rich pocket occurs in the feldspar zone of the pegmatite.

\section{Results and Discussions}

\section{Petrography and mineralogy of pegmatites}

The studied pegmatites show great similarity in their principal minerals to the host Abu Samyuk granite, essentially they are coarse granite. The principle constituents of the feldspar-rich samples are k-feldspar (perthite) and quartz, with minor plagioclase. They are inequigranular to equigranular and display typical pegmatite macrographic textures in quartz and feldspars (Fig. 3a). The feldspars are partially sericitized or stained by hematite. In some instances, the contact between k-feldspar crystals shows reaction rims mostly filled with quartz (Fig. 3b). Muscovite is mostly interstitial between quartz and K-feldspar (Fig. 3c). In the Fe-rich sample, the main mineral is iron oxides besides minor quartz and k-feldspar (Fig. 3d). Muscovite is also occurs as irregular flakes.

Fig. 3 Photomicrographs of Abu Samyuk pegmatites, (a) Graphic-like texture between quartz and k-feldspar, C. N., (b) Reaction rim filled with quartz between $\mathrm{k}$-feldspar crystals, $\mathrm{C}$. N., (c) Muscovite enclosed in quartz, C. $\mathrm{N}$. and (d) Iron oxides from the radioactive Fe-rich sample $\mathrm{C}$. N. abbreviations, Fd: K-feldspar, Qz: quartz, Ms: muscovite, Fe: iron oxides.
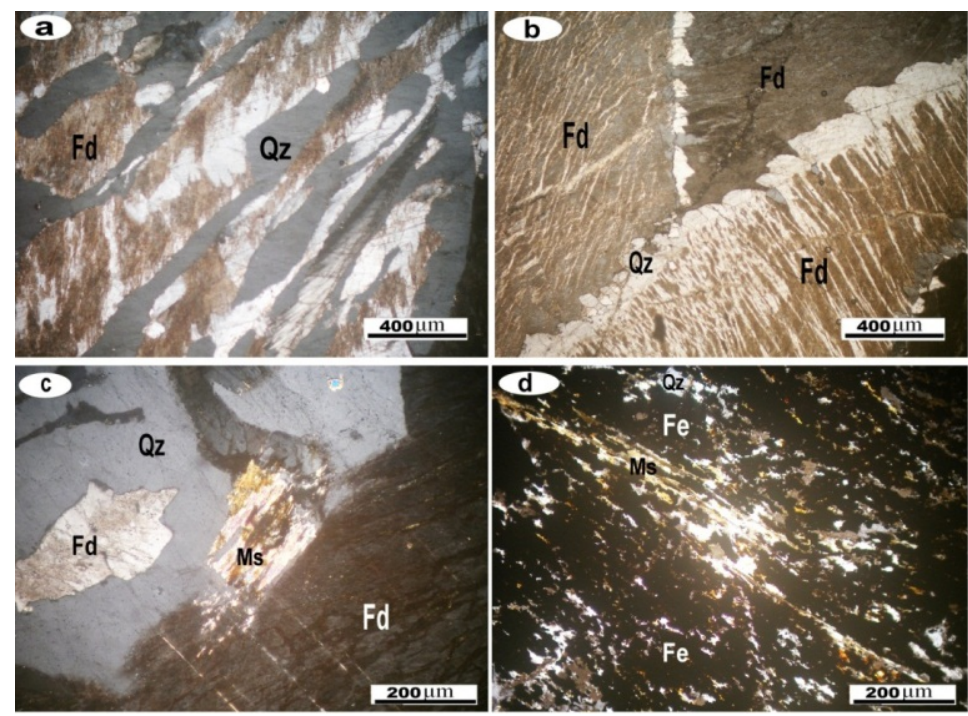

The rare metal-bearing minerals are not displayed in the prepared thin sections and they were picked from the separated heavy mineral fractions. The following minerals have been reported in the studied radioactive pegmatites: 


\section{Rare elements distribution and mineralization potentiality of pegmatites}

Zircon is abundant in all pegmatite samples. It is occurs as subhedral crystals of prismatic and dipyramidal forms. Their colors are principally brown although dark brown and yellow are also encountered. The studied zircon grains show cracks due to deuteric alteration, indicating that they are metamict zircon (Geisler et al. 2003, 2007; Xu et al. 2012). The ESEM image and EDS analysis of zircon indicated that it consists of $\mathrm{Zr}$ and $\mathrm{Si}$ with minor $\mathrm{Al}, \mathrm{Ca}, \mathrm{Fe}$ and $\mathrm{Hf}$. The occurrence of zircon in the individual sample affects directly on the radioactivity level. Zircon is the main carrier for $U$ and $T h$ in the studied pegmatites (Fig. 4a).

Columbite-( $\mathrm{Fe})$ is present in variable amounts in all pegmatite samples. It is present as subhedral prismatic crystals of black color and dull luster. The obtained EDS analysis of columbite-( $\mathrm{Fe})$ clarifies the presence of $\mathrm{U}, \mathrm{Th}, \mathrm{Y}$ and REE, which contribute also on the total radioactivity of the samples (Fig. 4b). Columbite-( $\mathrm{Fe})$ shows high concentrations of $\mathrm{Nb}$ and lower contents of $\mathrm{Ta}$ and in some examples $\mathrm{Ta}$ is absent.

The rare earth-bearing minerals are represented mainly by fergusonite-( $\mathrm{Y})$ and its high contents are present in the body $(\mathrm{P}-1)$. Its grains are irregular in shape, but several have a prismatic habit. On the surface, the grains have a very thin layer of dull, dark brownish-grey alteration. The broken surface is dark brown with a resinous luster. The EDS analysis of fergusonite- $(\mathrm{Y})$ confirmed the presence of $\mathrm{Nb}, \mathrm{Y}$ and REE as major components, while $U$ and Th are present in trace amounts (Fig. 4c). Minor amount of undefined REE-bearing mineral is present as massive anhedral grains with brownish red color. The EDS spectrums of these grains show elevated concentrations of $\mathrm{Y}$ and REE (Ce) in addition to $\mathrm{U}$ and $\mathrm{Th}$ (Fig. $4 d)$.

Fluorite occurs in all pegmatite samples as anhedral to subhedral grains, which exhibiting wide range of colors from colorless, pale blue to dark violet with vitreous and resinous luster. The role of F-rich fluids during the evolution of the studied pegmatites can be deduced by the widespread abundance of fluorite among their contained accessory minerals. The ESEM image and EDS spectrum of fluorite grains are illustrated in Figure (4e).

Xenotime- $(\mathrm{Y})$ is registered only in the Fe-rich body (P-2), which occurring as minute crystals in the polished section. It is found as anhedral fine crystals interstitial the iron oxide minerals. The ESEM image and EDS analysis of xenotime are displayed in Figure (4f).

\section{Geochemistry of the pegmatites}

Major, trace and rare earth concentrations with parameters and ratios of the six pegmatite samples were listed in Table (1). Five samples from the feldspar-rich zones and one sample represent the Fe-rich pocket. The mean values of G. Abu Samyuk granite reported by Mahdy et al. (2015) were given for comparison. The Fe-rich sample is analyzed only to assess its potentiality of the rare elements, although its major oxide concentrations are highly deviated from the feldspar-rich samples and the averages of Abu Samyuk granite.

\section{Major and trace element abundances}

The major element compositions for the investigated pegmatites identify the granitic nature of these rocks and their advanced degree of magmatic evolution. Relative to Abu Samyuk granite, the feldspar-rich samples have low silica contents (av. $70.20 \mathrm{wt} . \%$ ) and slightly higher concentrations of total iron (3.21 wt.\%), $\mathrm{CaO}$ (av. 1.27 wt.\%) and $\mathrm{Na}_{2} \mathrm{O}$ (av. 4.82 wt.\%). The other oxides are relatively constant with $\mathrm{TiO}_{2}$ (av. 0.15 wt.\%), $\mathrm{Al}_{2} \mathrm{O}_{3}$ (av. 13.55 wt.\%), $\mathrm{MnO}$ (av. 0.03 wt.\%), $\mathrm{MgO}$ (av. 0.15 wt.\%), $\mathrm{K}_{2} \mathrm{O}$ (av. 4.90 wt.\%) and $\mathrm{P}_{2} \mathrm{O}_{5}$ (av. 0.07 wt.\%). In the Fe-rich sample, it is highly depleted in all major oxides, except the main component total iron (Table 1).

The trace elements show different degrees of enrichments and depletions relative to the host granite. $\mathrm{Nb}$ (av. $584 \mathrm{ppm}$ ), Y (av. $426 \mathrm{ppm}$ ) and $\mathrm{Zr}$ (av. $1015 \mathrm{ppm}$ ) are strongly enriched, while Hf (av. $73 \mathrm{ppm}$ ), Th (av. $190 \mathrm{ppm}$ ) and $\mathrm{U}$ (av. $122 \mathrm{ppm}$ ) show significant changes. As a result, the studied pegmatites could be classified as NYF-type pegmatites (Černý 1991). The chalcophile elements $\mathrm{Pb}$ (av. 83 ppm) and Zn (av. 
$235 \mathrm{ppm}$ ) display higher values. Ga (av. $61 \mathrm{ppm}$ ) is highly enriched compared to Abu Samyuk granite, which probably is not controlled by K-feldspar fractionation but is buffered by other phases (Larsen 2002). The large ion lithophile elements $\mathrm{Rb}, \mathrm{Sr}$ and $\mathrm{Ba}$ show wide variations in composition when compared with the host granite. Barium is depleted (av. $39 \mathrm{ppm}$ ) and $\mathrm{Rb}$ is enriched (av. $252 \mathrm{ppm}$ ), while $\mathrm{Sr}$ (av. $33 \mathrm{ppm}$ ) is relatively remain constant. The trace elements in the Fe-rich sample select the same behavior with high abundances of $\mathrm{Zr}, \mathrm{Nb}, \mathrm{Ta}, \mathrm{Y}$, Th and $\mathrm{U}$ and $\mathrm{Zn}$.

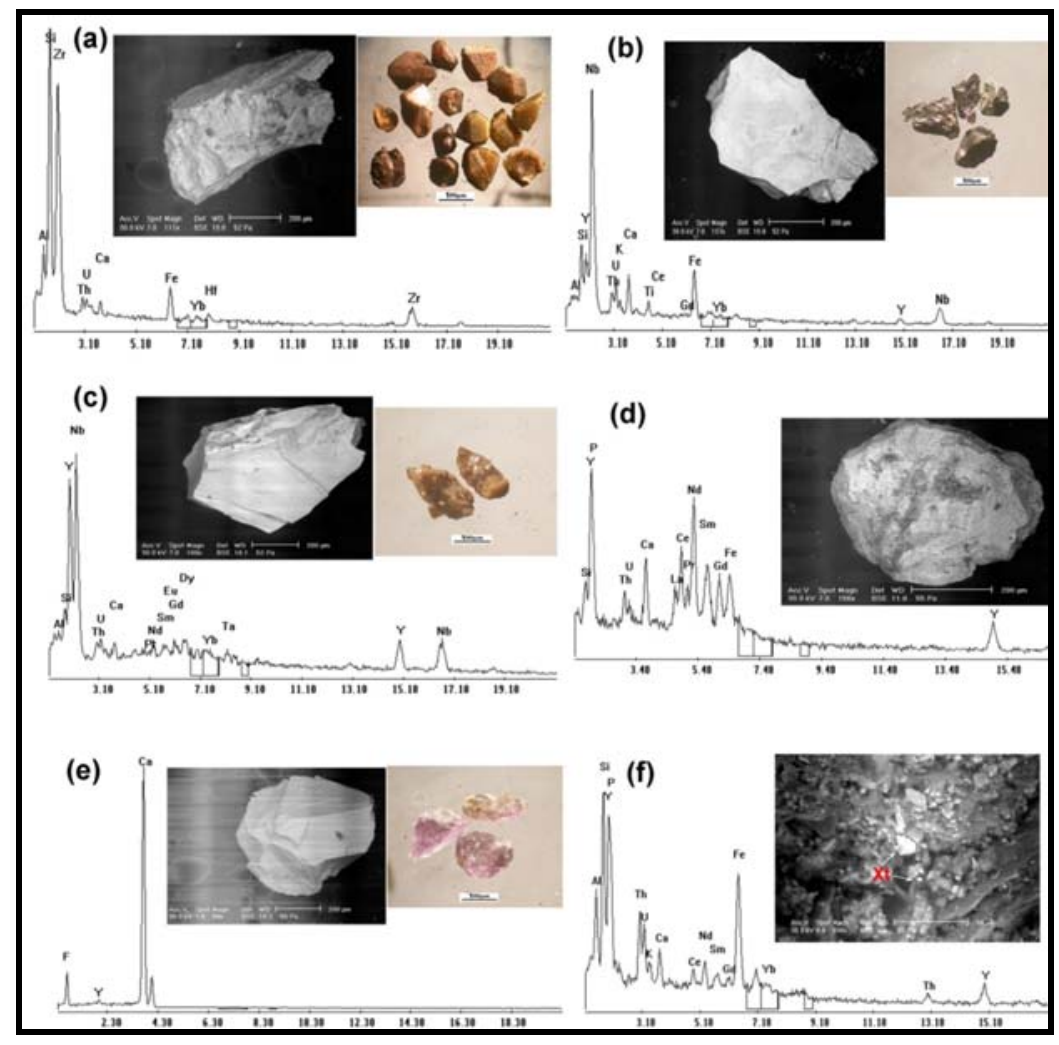

Fig. 4: (a) mineral grains (binocular microscope), ESEM image and EDS analysis of zircon, (b) mineral grains (binocular microscope), ESEM image and EDS spectrum of columbite (Fe), (c) mineral grains (binocular microscope), ESEM image and EDS analysis of fergusonite-(Y), (d) ESEM image and EDS spectrum of REE-bearing mineral, (e) mineral grains (binocular microscope), ESEM image and EDS analysis of fluorite and (f) ESEM image and EDS spectrum of xenotime-(Y) in polished section.

$\mathrm{The} \mathrm{Nb} / \mathrm{Ta}$ ratios for the feldspar-rich samples have average 6.1, which is lower than the average ratio of Abu Samyuk granite 12.4. Decreasing Nb/Ta is typical of NYF granitic pegmatites and may indicate a high activity of $\mathrm{F}$, promoting the fractionation of $\mathrm{Nb}$ and Ta (Černý et al. 1986; Černý 1991). Primitive-mantle melts have rather constant $\mathrm{Nb} / \mathrm{Ta}$ ratios of $17.5 \pm 2$ (Hofmann et al. 1986; Green 1995), a value comparable to that of chondrites (Sun and McDonough 1989).

The average $\mathrm{Zr} / \mathrm{Hf}$ ratio is 11.8 for pegmatite samples, which is extremely lower than the average 24.9 of Abu Samyuk granite. There is an increase in Hf, with relatively constant $\mathrm{Zr} / \mathrm{Hf}$ ratios. In granitic pegmatites, $\mathrm{Hf}$ is enriched with respect to $\mathrm{Zr}$ in the zircons, especially in the late stages of pegmatite crystallization (Owen, 1987; Uher and Cerny, 1998). However, the average $\mathrm{Zr} / \mathrm{Hf}$ ratio of whole-rock analyses of pegmatites is about 25, proposed by Erlank et al. Erlank et al. (1978). Wang et al. (2010) explained the lower $\mathrm{Zr} / \mathrm{Hf}$ ratio in granitic zircon by lower crystallization temperature, which increases the $\mathrm{D}_{\mathrm{Hf}}$ between zircon and granitic magma. Also, the lower $\mathrm{Zr} / \mathrm{Hf}$ ratio is a good parameter for the crystallization of hydrothermal zircon (Caironi et al. 2000).

The trace elements data of pegmatite are normalized to the primitive mantle (Sun \& McDonough 1989) and compared with the average host granite on the spider diagram. It shows trace element pattern similarities amongst the samples but with higher values compared to host rock. Such similarities suggesting that the studied pegmatites and the host granite are all petrogenetically related to the same province. The pegmatite samples are enriched in $\mathrm{Cs}, \mathrm{Rb}, \mathrm{Th}, \mathrm{U}, \mathrm{Nb}, \mathrm{Ta}, \mathrm{K}, \mathrm{Pb}, \mathrm{Zr}$, and $\mathrm{REE}$ and depleted in $\mathrm{Ba}, \mathrm{Sr}, \mathrm{P}$, and Ti (Fig. 5). 
Rare elements distribution and mineralization potentiality of pegmatites

Table 1 Whole rock chemical analysis with parameters and ratios of the studied pegmatites.

\begin{tabular}{|c|c|c|c|c|c|c|c|c|}
\hline & \multirow{2}{*}{$\begin{array}{c}\text { Av. Abu Samyuk } \\
\text { granite } \\
\text { (Mahdy et al. } \\
\text { 2015) } \\
\end{array}$} & \multicolumn{6}{|c|}{ Feldspar-rich pegmatite samples } & \multirow{2}{*}{$\begin{array}{c}\begin{array}{c}\text { Fe-rich } \\
\text { pegmatite } \\
\text { sample }\end{array} \\
\text { P-2 } \\
\end{array}$} \\
\hline & & P-1 & P-3 & P-4 & P-5 & P-6 & Av. & \\
\hline \multicolumn{9}{|c|}{ Major oxides (wt. \%) } \\
\hline $\mathrm{SiO}_{2}$ & 75.16 & 65.02 & 73.2 & 76.51 & 63.35 & 72.91 & 70.20 & 45.82 \\
\hline $\mathrm{TiO}_{2}$ & 0.11 & 0.49 & 0.03 & 0.03 & 0.18 & 0.03 & 0.15 & 0.37 \\
\hline $\mathrm{Al}_{2} \mathrm{O}_{3}$ & 13.37 & 14.39 & 13.15 & 11.67 & 15.01 & 13.2 & 13.55 & 8.95 \\
\hline $\mathrm{Fe}_{2} \mathrm{O}_{3} \mathrm{t}$ & 1.24 & 3.81 & 0.84 & 1.22 & 8.69 & 1.5 & 3.21 & 39.24 \\
\hline MnO & 0.03 & 0.04 & 0.01 & 0.01 & 0.09 & 0.02 & 0.03 & 0.78 \\
\hline MgO & 0.10 & 0.27 & 0.08 & 0.12 & 0.23 & 0.05 & 0.15 & 0.25 \\
\hline $\mathrm{CaO}$ & 0.78 & 4.31 & 0.48 & 0.46 & 0.7 & 0.42 & 1.27 & 0.66 \\
\hline $\mathrm{Na}_{2} \mathrm{O}$ & 3.71 & 5.6 & 5.10 & 4.02 & 3.29 & 6.1 & 4.82 & 0.36 \\
\hline $\mathrm{K}_{2} \mathrm{O}$ & 4.67 & 4.1 & 5.34 & 4.69 & 6.24 & 4.13 & 4.90 & 1.07 \\
\hline $\mathbf{P}_{2} \mathrm{O}_{5}$ & 0.02 & 0.16 & 0.04 & 0.03 & 0.08 & 0.06 & 0.07 & 0.18 \\
\hline L.O.I & & 1.81 & 1.73 & 1.24 & 2.14 & 1.58 & & 2.32 \\
\hline \multicolumn{9}{|c|}{ Trace elements (ppm) } \\
\hline Ba & 124 & 43 & 33 & 38 & 38 & 41 & 38.6 & 19 \\
\hline $\mathbf{R b}$ & 93 & 169 & 278 & 261 & 349 & 203 & 252 & 75 \\
\hline $\mathrm{Sr}$ & 30 & 51 & 24 & 18 & 35 & 38 & 33 & 67 \\
\hline Cs & 1.2 & 5.2 & 2.9 & 3.4 & 3.9 & 1.5 & 3.4 & 1.5 \\
\hline Ga & 22 & 55 & 59 & 49 & 90 & 54 & 61 & 84 \\
\hline Ta & 2.1 & 270 & 8 & 40 & 37 & 9 & 73 & 88 \\
\hline $\mathbf{N b}$ & 26 & 2389 & 32 & 92 & 355 & 50 & 584 & 588 \\
\hline Hf & 3.8 & 252 & 13 & 23 & 50 & 28 & 73 & 13 \\
\hline $\mathrm{Zr}$ & 94 & 3746 & 124 & 249 & 670 & 285 & 1015 & 149 \\
\hline $\mathbf{Y}$ & 31 & 1502 & 53 & 265 & 237 & 74 & 426 & 1034 \\
\hline $\mathrm{Ni}$ & 3.1 & 1.3 & 2.3 & 2.6 & 2.3 & 2.4 & 2.2 & 2.1 \\
\hline $\mathrm{Cr}$ & 44 & 8 & 7 & 9 & 9 & 9 & 8 & 7 \\
\hline Co & 2.4 & 1.9 & 0.6 & 1.0 & 0.8 & 0.5 & 1.0 & 4.0 \\
\hline $\mathbf{V}$ & 4 & 17 & 4 & 3 & 14 & 5 & 9 & 24 \\
\hline $\mathrm{Cu}$ & 6 & 3 & 3 & 3 & 7 & 77 & 19 & 10 \\
\hline $\mathbf{P b}$ & 16 & 106 & 26 & 87 & 46 & 150 & 83 & 41 \\
\hline $\mathbf{Z n}$ & 77 & 294 & 76 & 169 & 423 & 213 & 235 & 5835 \\
\hline Th & 9.7 & 705 & 26 & 65 & 96 & 58 & 190 & 122 \\
\hline $\mathbf{U}$ & 5.3 & 461 & 14 & 41 & 60 & 36 & 122 & 160 \\
\hline $\mathrm{Nb} / \mathrm{Ta}$ & 12.4 & 8.9 & 4.1 & 2.3 & 9.5 & 5.6 & 6.1 & 6.7 \\
\hline $\mathrm{Zr} / \mathrm{Hf}$ & 24.9 & 14.9 & 9.3 & 11.0 & 13.4 & 10.5 & 11.8 & 11.9 \\
\hline $\mathrm{Th} / \mathrm{U}$ & 1.85 & 1.53 & 1.93 & 1.59 & 1.61 & 1.61 & 1.65 & 0.76 \\
\hline \multicolumn{9}{|c|}{ Rare earth elements } \\
\hline $\mathbf{L a}$ & 48 & 27 & 12 & 79 & 7 & 4 & 26 & 52 \\
\hline Ce & 108 & 162 & 27 & 304 & 23 & 67 & 117 & 203 \\
\hline Pr & 15 & 31 & 4 & 36 & 6 & 2 & 16 & 30 \\
\hline Nd & 53 & 198 & 16 & 142 & 26 & 7 & 78 & 155 \\
\hline Sm & 11 & 107 & 6 & 44 & 15 & 30 & 35 & 73 \\
\hline Eu & 0.6 & 0.2 & 0.1 & 0.2 & 0.1 & 0.1 & 0.14 & 0.2 \\
\hline Gd & 8 & 134 & 7 & 53 & 21 & 4 & 44 & 92 \\
\hline Tb & 1.4 & 32 & 1.3 & 8.8 & 5 & 1 & 9.6 & 21 \\
\hline Dy & 6.7 & 246 & 8.1 & 50 & 39 & 10 & 71 & 151 \\
\hline Ho & 1.2 & 55 & 1.9 & 8.8 & 9 & 2.8 & 16 & 33 \\
\hline $\mathrm{Er}$ & 3.5 & 193 & 5.8 & 25 & 32 & 12 & 54 & 110 \\
\hline Tm & 0.5 & 34 & 1.2 & 3.7 & 6 & 2.6 & 9 & 21 \\
\hline Yb & 3.2 & 242 & 10 & 27 & 44 & 23 & 69 & 137 \\
\hline Lu & 0.4 & 35 & 1.6 & 3.9 & 7.2 & 4.0 & 10.4 & 21 \\
\hline 2REE & 259 & 1496 & 102 & 786 & 240 & 141 & 553 & 1097 \\
\hline LREE & 223 & 418 & 59 & 561 & 62 & 80 & 236 & 440 \\
\hline MREE & 27 & 519 & 22 & 156 & 80 & 18 & 159 & 336 \\
\hline HREE & 9 & 559 & 20 & 69 & 98 & 44 & 158 & 322 \\
\hline \multicolumn{9}{|c|}{ Normalized ratios (Anders and Grevesse, 1989) } \\
\hline$(\mathbf{L a} / \mathbf{L u})_{\mathrm{N}}$ & 12.3 & 0.08 & 0.78 & 2.09 & 0.10 & 0.10 & 0.63 & 0.26 \\
\hline$(\mathbf{L a} / \mathrm{Sm})_{\mathrm{N}}$ & 2.84 & 0.16 & 1.34 & 1.12 & 0.29 & 0.93 & 0.77 & 0.45 \\
\hline$(\mathrm{Gd} / \mathrm{Lu})_{N}$ & 2.55 & 0.47 & 0.56 & 1.68 & 0.37 & 0.11 & 0.64 & 0.55 \\
\hline Eu/Eu* & 0.20 & 0.01 & 0.05 & 0.01 & 0.02 & 0.10 & 0.04 & 0.01 \\
\hline $\mathrm{Ce} / \mathrm{Ce}^{*}$ & 0.90 & 5.42 & 0.12 & 11.59 & 2.10 & 0.41 & 3.93 & 3.84 \\
\hline
\end{tabular}

$\mathrm{Eu} / \mathrm{Eu}^{*}=$ the value of the Eu anomaly calculated by the formula $\mathrm{Eu} / \mathrm{Eu}^{*}=\left[\left(\mathrm{Eu}_{\mathrm{N}}\right) /\left(\mathrm{SQ}^{\mathrm{R}}\left(\mathrm{Sm}_{\mathrm{N}} \mathrm{Gd}_{\mathrm{N}}\right)\right] ; \mathrm{Ce} / \mathrm{Ce}\right.$ * $=$ the value of the Ce anomaly calculated by the formula $\mathrm{Ce} / \mathrm{Ce}^{*}=\left[\left(\mathrm{Ce}_{\mathrm{N}}\right) /\left(\mathrm{SQR}\left(\mathrm{La}_{\mathrm{N}} \mathrm{Pr}_{\mathrm{N}}\right)\right]\right.$, from Worrall and Pearson (2001). 


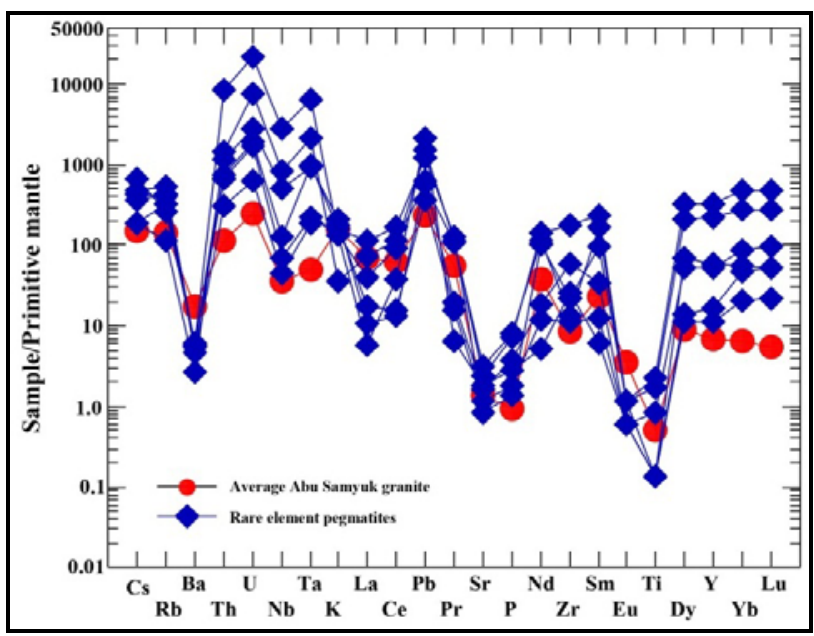

Fig. 5: Primitive-mantle normalized multi-element diagram of the studied pegmatites.

\section{Uranium and thorium distribution}

$\mathrm{U}$ and Th contents have a wide range in all investigated pegmatites. $\mathrm{U}$ is ranging from $14 \mathrm{ppm}$ to 461 ppm, much higher than the average $(5 \mathrm{ppm})$ of Abu Samyuk granite. Also, Th concentrations show a wide range from 26 to $705 \mathrm{ppm}$, which are also higher than the average (10 ppm) of Abu Samyuk granite. This wide range is depending mainly upon the abundances of U-Th-bearing minerals such as zircon, fergusonite$(\mathrm{Y})$ and columbite-(Fe) in the individual sample. There is a strong positive correlation between $\mathrm{U}$ and Th (Fig. 6a), indicated that $U$ and $T h$ are linked and accommodated together in their bearing minerals. The highly positive relationship between $\mathrm{Zr}$-Th and $\mathrm{Zr}-\mathrm{U}$ (Figs. 6b,c) imply that the enrichment of $\mathrm{U}$ and Th are mainly controlled by the abundance of zircon in the individual sample, while the other U-Th-bearing phases such as fergusonite-(Y) and columbite-(Fe) are present in low amount compared to zircon. The $\mathrm{Th} / \mathrm{U}$ ratios are ranging from 0.76 to 1.93 , much lower than those reported in the literature (3-4.5) for granitic rocks (Rogers and Adams 1969; Faüre 1986), mainly due to the higher U concentrations.
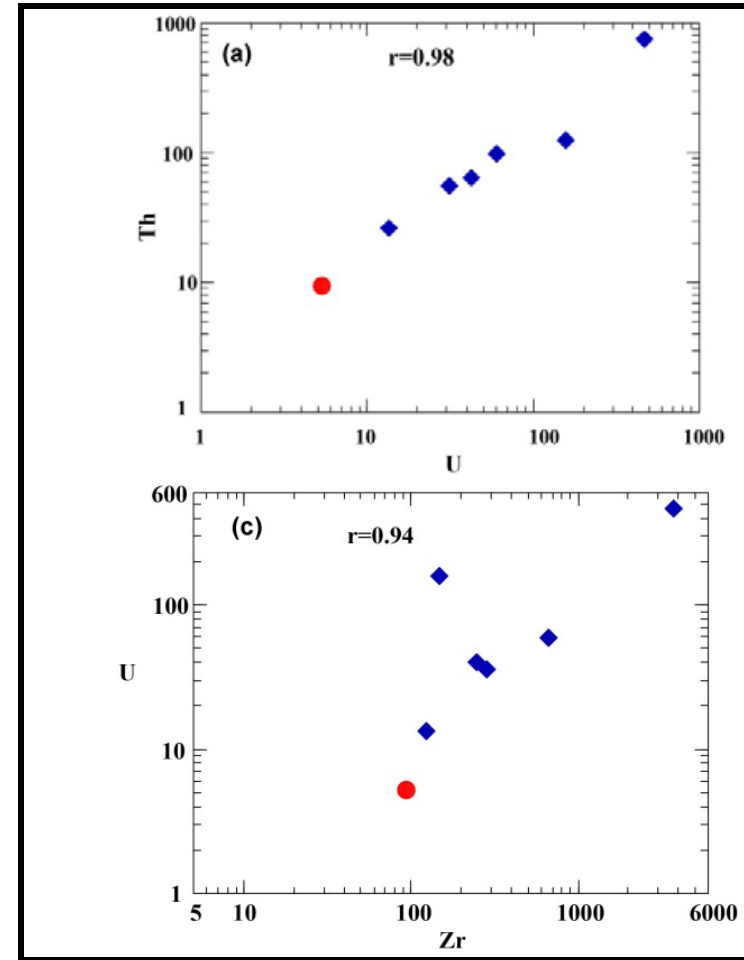

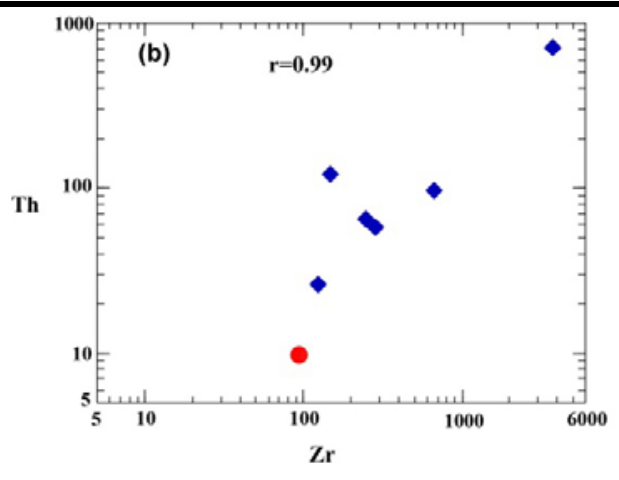

Fig. 6: log-log variation diagrams between (a) U-Th, (b) Zr-Th and (c) Zr-U for the studied pegmatites $\bullet$ : average Abu Samyuk granite, $\$$ : rare metal pegmatites 
Rare elements distribution and mineralization potentiality of pegmatites

\section{Rare earth elements}

The rare earth element concentrations and normalized ratios (Anders and Grevesse, 1989) of the investigated pegmatites were given in Table 1 . The $\Sigma$ REE contents are varying between 102 and $1496 \mathrm{ppm}$ with average $553 \mathrm{ppm}$ for the feldspar-rich samples, markedly higher than that of the host rock $259 \mathrm{ppm}$ (Table 1). The Fe-rich sample contains $\mathrm{REE}(1097 \mathrm{ppm})$ much higher that of the surrounded granite. The chondrite-normalized REE patterns (Sun \& McDonough 1989) of the average host rock and pegmatite samples are shown in Figure (7). The host rock is characterized by negative Eu anomaly and enrichment of LREE relative to MREE and HREE. On the contrary, the pegmatite samples show similar pattern of negative Eu anomaly but with reverse depletion-enrichment trend from LREE to MREE and HREE. As a result of this trend, the $(\mathrm{La} / \mathrm{Lu}) \mathrm{N}(\mathrm{La} / \mathrm{Sm}) \mathrm{N}$ and the $(\mathrm{Gd} / \mathrm{Lu}) \mathrm{N}$ ratios decreased in all pegmatite samples relative to host granite (Table 1). The $\mathrm{Eu} / \mathrm{Eu}^{*}$ values were decreased, and the $\mathrm{Ce} / \mathrm{Ce} *$ values were highly increased relative to the host rock as would be expected for this NYF-system (Table 1).

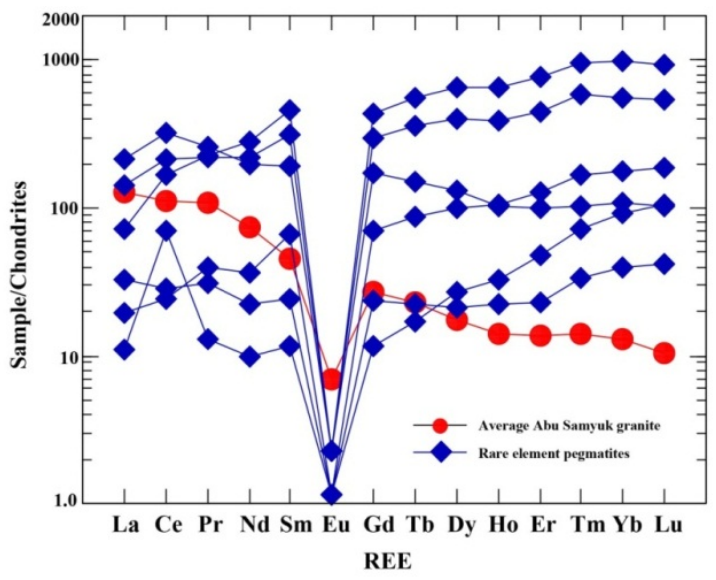

Fig. 7: Chondrite-normalized REE patterns of the investigated pegmatites.

\section{MINERALIZATION POTENTIALITY}

Based on field and textural relations, mineralogical and geochemical data, the studied pegmatites are consistent with fractional crystallization trend from granites toward pegmatites. They are characterized by zoning structure that is typical of highly fractionated and mineralized pegmatites (Sweetapple 2000). The studied pegmatites had undergone increasing fractionation and concentration of rare elements and volatiles. The collected data indicated that Abu Samyuk pegmatites are mineralized as many Precambrian pegmatites in the Basement Complex of Egypt. These pegmatite bodies show an overall enrichment in HFSE concentrations, which behave incompatibly in silica-saturated alkaline magma.

The mineralogical studies of Abu Samyuk pegmatites have provided evidence that zircon, fergusonite$(\mathrm{Y})$, columbite-(Fe) and xenotime-(Y) are the major $\mathrm{U}-$, Th-, Nb- and REE-bearing minerals, which concentrated within the outer zones of the pegmatites. The abundances of the mineralization are extremely variable among the pegmatite bodies. Pegmatites in the area have a wide range of mineralization potential from medium to high mineralized bodies.

The investigated pegmatites document higher contents of HFSE. The pegmatites are enriched in $\mathrm{Zr}, \mathrm{Nb}$, $\mathrm{U}$, Th and REE, which are the major mineralization indices for pegmatite bodies in the Egyptian Basements. The trace element parameters support a high degree of fractionation in the evolutionary history of the pegmatites. These features agrees with the moderately positive $\mathrm{Ce}$ signature and negative Eu anomaly REE pattern exhibited by mostly the bulk rock pegmatites. The overall geochemical signatures of Abu Samyuk pegmatites generally indicate high fractionation, and high level of rare metal mineralization potential, such as the rare metal pegmatites in the North Eastern Desert of Egypt Egypt (Ali 2007; Nossair 1987; Mohamed et al. 1994; Asran et al. 2013). 


\section{CONCLUSIONS}

Simple zoned pegmatite bodies of lenticular and irregular shapes are evolved within Abu Samyuk granite, North Eastern Desert, Egypt. Among them, six bodies contain radioactive anomalies in their outer zones. Thin sections studies indicated that the pegmatites and their enclosing granitic rocks have the same mineral composition of perthite, quartz and less abundant plagioclase with minor accessory phases of micas. The mineralogical observations of the heavy mineral grains document variable abundances of $\mathrm{Zr}$ Th-U-Nb-REE-rich minerals such as zircon, fergusonite-(Y), columbite-(Fe) and xenotime-(Y). Chemical analysis of the whole rock samples show that they are NYF-type pegmatite, which are clearly enriched in $\mathrm{Zr}, \mathrm{U}, \mathrm{Th}, \mathrm{Nb}$ and REE compared to the host granite such as many pegmatites in the Basement Complex of Egypt. The high levels of rare metal mineralization in some pegmatite bodies make them a target to dig exploratory trenches to enlarge the potentiality of the highly mineralized bodies.

\section{REFERENCES}

Abu Zaid, M. (1995): Relation between surface and subsurface uranium mineralization and structural features, Gabal Gattar, north Eastern Desert, Egypt. M Sc Thesis, Fac Sci, Ain Shams Univ, 208pp

Akaad, M. K., Nowier A. M. (1980): Geology and lithostratigraphy of the Arabian Desert orogenic belt of Egypt between lat. $25^{\circ} 35^{\prime}$ and $25^{\circ} 30^{\prime}$. Inst App Geol Jeddah Bull 3,127-135.

Ali, B. A. (2007): Geochemistry of U-Th- REE bearing minerals, in radioactive pegmatite in Um SwassiDara area, north eastern desert, Egypt. AEC Jordan 1, 197-209.

Anders, E., Grevesse, N. (1989) Abundances of the elements: meteoritic and solar. Geochim et Cosmochim 53, 197-214.

Asran, A. M. H., El Mansi, M. M., Ibrahim, M. E. and Abdel Ghani, I. M. (2013): Pegmatites of Gabal El Urf, Central Eastern Desert, Egypt. The $7^{\text {th }}$ inter. Conf. geology of Africa, P-P IV-1-V-22, Assuit, Egypt.

Atia, M. S., Kabesh, M. L., Dawoud, M. (1998): Geochemistry, tectonic setting and classification of some granitoids, Gebel Abu El-Hasan, North Eastern Desert, Egypt. Acta Mineralogica-Petrographica, Szeged, XXXIX, 49-76.

Ayoub, R. R. (1997): Geology and radioactivity of Gabal Um Dissi area, Central Desert, Egypt. M. Sc. Thesis, Fac. Sci., Cairo Univ., 193pp

Beyth, M., Stern, R. J., Altherr R, Kröner, A. (1994): The late Precambrian Timna igneous complex, southern Israel: evidence for comagmatic-type Sanukitoid monzodiorite and alkali granite magma. Lithos 31, 103- 124.

Caironi, V., Colombo A., Tunesi A., Gritti C. (2000): Chemical variations of zircon compared with morphological evolution during magmatic crystallization: an example from the Valle del Cervo Pluton (Western Alps). Eur J. Mineral., 12, 779-794.

Černý, P. (1991): Rare-element granitic pegmatites. 1. Anatomy and internal evolution of pegmatite deposits. Geosci., Canada 18, 49-67.

Černý, P, Ercit TS (2005): The classification of granitic pegmatites revisited. Canad. Mineral., 43, 20052026.

Černý, P., Goad B. E., Hawthorne F. C., Chapman R. (1986): Fractionation trends of the Nb and Ta-bearing oxide minerals in the Greer Lake pegmatitic granite and its pegmatite aureole, southeastern Manitoba. Am. Mineral., 71, 501-517.

Černý, P., London D., Novak M. (2012): Granitic pegmatites as reflections of their sources. Elements 8, 289-294.

El Dabe, M. M. (2010): Geology, geochemistry and radioactivity of some alkali feldspar granite intrusions in the North Eastern Desert, Egypt. Ph. D. Thesis, Fac. Sci., Assuit Univ.,133pp.

El Gaby, S., List F. K., Taharani R. (1988): Geology, evolution and metallogenesis of the Pan-African belt in Egypt, In S El Gaby, and R O Greiling (eds), The Pan-African belt of Northeast Africa and adjacent areas. Tectonic evolution and economic aspects of the Late Proterozoic arogen. Fried Niewing and Sohn, Brausschweig, Viesbaden, 17-68.

El Gaby, S., List, F. K., Tehrani, R. (1990): The basement complex of the Eastern Desert and Sinai. In: R 


\section{Rare elements distribution and mineralization potentiality of pegmatites}

Said, (eds), The Geology of Egypt, Balkema-Rotterdam-Bookfield, Holland, 175-184.

El Rakaiby, M. L., Shalaby, M. H. (1988): Geology of Gabal Qattar batholith, central Eastern Desert, Egypt. Int. J. Rem. Sens., 13, 2337-2347.

El Sayed, M. M. (1998): Tectonic setting and petrogenesis of the Kadabora pluton: a late Proterozoic anorogenic A-type younger granitoid in the Egyptian Shield. Chem Erde 58, 38-63.

El Sayed, M. M., Shalaby, M. H., Hassanen, M. A. (2003): Petrological and geochemical constraints on the tectonomagmatic evolution of the late Neoproterozic granitoid suites in the Gattar area, North Eastern Desert, Egypt. N. Jb Miner Abh J Miner Geochem 178, 239-275.

El Sundoly, H., I. (2008): The relation between tectonics of some granitoids rocks and radioelement distribution, W. Abu El Hassan area, North Eastern Desert, Egypt. Ph. D Thesis, South Valley Univ., $319 \mathrm{pp}$

Erlank, A. J, Smith, H. S., Marchant, J. W., Cardoso, M. P., Ahrens L. H. (1978): Hafnium. Handbook of Geochemistry (Wedepoh1 K H, ed), 72C1-72O1, Springer- Verlag, Berlin, Heidelberg, New York.

Faüre, G. (1986): The U, Th- $\mathrm{Pb}$ methods of dating. In: Principles of isotope geology (2nd Ed.). John Wiley \& Sons, 228- 308.

Furnes H., El-Sayed M M, Khalil SO, Hassanen M A (1996): Pan-African magmatism in the Wadi El Imra district, Central Eastern Desert, Egypt: geochemistry and tectonic environment. J Geol Soc London 153, 705-718.

Geisler, T, Rashwan, A. A., Rahn, M. K. W., Poller, U., Zwingmann, H., Pidgeon, R. T., Schleicher, H., Tomaschek, F. (2003): Low-temperature hydrothermal alteration of natural metamict zircons from the Eastern Desert, Egypt. Mineral Mag 67, 485-508.

Geisler, T., Schaltegger, U., Tomaschek, F. (2007): Re-equilibration of zircon in aqueous fluids and melts. Elements 3, 43-50.

Green, T. H. (1995): Significance of NbrTa as an indicator of geochemical processes in the crust-mantle system. Chem Geol 120, 347-359.

Hassan, M. A., Hashad, A. H. (1990): Precambrian of Egypt. In: R Said (ed.). The Geology of Egypt, Balkema, Rotterdam, 201-245.

Hofmann, A. W., Jochum, K. P., Seufert, M., White, W. M. (1986): Nb and Pb in oceanic basalts: new constraints on mantle evolution. Earth Planet Sci Lett 79, 33-45.

Hussein, A A A, Ali MM, El Ramly M F (1982): A proposed new classification of the granites of Egypt. J Volcanol Geotherm Res14, 187-198.

Larsen, R B (2002): The distribution of rare-earth elements in K-feldspars as an indicator of petrogenetic processes in granitic pegmatites: examples from two pegmatite fields in southern Norway. Can Mineral 40, 137-151.

Mahdy, N. A., El Kalioubi, B, A,, Wohlgemuth-Ueberwasser, C. C. Shalaby, M. H., El Afandy, A. H. (2015): Petrogenesis of U- and Mo-bearing $\mathrm{A}_{2}$-type granite of the Gattar batholith in the Arabian Nubian Shield, Northeastern Desert, Egypt: Evidence for the favorability of host rocks for the origin of associated ore deposits. Ore Geol Rev 71, 57-81.

Moghazi, A. M. (1999): Magma source and evolution of late Neoproterozoic granitoids in the Gabal El Urf area, Eastern Desert, Egypt: geochemical and Sr-Nd isotopic constrains. Geol Mag 136, 285-300.

Mohamed, F. H., Hassanen M. A., Shalaby, M. H. (1994): Geochemistry of Wadi Hawashia granite complex, Northern Egyptian Shield. J Afr Earth Sci 19, 61-74.

Moussa, E. M., Stern R. J., Manton W. J., Ali K. A. (2008): SHRIMP zircon dating and Sm/Nd isotopic investigations of Neoproterozoic granitoids, Eastern Desert, Egypt. Precambr Res 160, 341-356.

Nossair, L M (1987): Structural and radiometric studies of Gebel Gharib area, north Eastern Desert, Egypt. Ph D Thesis, Fac Sci, Alex Univ, 182pp

Noweir, A M, Sewifi B M, Abu EI Ela A M (1990): Geology, petrography, geochemistry and petrogenesis of the Egyptian younger granites. Qatar Univ Sci 10, 363-393.

Owen, M. R. (1987): Hafnium content of detrital zircons, a new tool for provenance study. J Sediment Petrol., 57, 824-830.

Rogers, J. J. W., Adams, J. A. S. (1969): Thorium-Uranium. In: K. H. Wedepohl (Ed.), Handbook of 
Geochemistry. Berlin, Springer-Verlag, 2(3), Chap.90 \& 92.

Roz, M. E. (1994) Geology and uranium mineralization of Gabal Gattar area, North Eastern Desert, Egypt. M. Sc. Thesis, Fac. Sci., Al-Azhar Univ., 175pp

Shalaby, M. H. (1985): Geology and radioactivity of W. Dara area, North Eastern Desert, Egypt. Ph. D. Thesis, Fac. Sci., Alex Univ., 165pp

Stern, R. J., Gottfried, D. (1986): Petrogenesis of a Late Precambrian (575-600Ma) bimodal Suite in northeast Africa. Contrib Mineral Petrol 92, 492-501.

Sun, S. S., McDonough, W. F. (1989): Chemical and isotopic systematic of oceanic basalts: implications for mantle composition and processes. In: Saunders A D, Norry M J (Eds), Magmatism in the Ocean Basins.

Sweetapple, M T (2000): Characteristics of Sn-Ta-Be-Li-Industrial Mineral Deposits of the Archaean Pilbara Craton, Western Australia. Canberra, Australian Geological Survey Organization. AGSO Record 2000/44: 54.

Uher P, Černý P (1998): Zircon in hercynian granitic pegmatites of the western Carpathians, Slovakia. Geologica Carpathica 49, 261-270.

Wang, X., Griffin, W. L., Chen, J. (2010): Hf Contents and Zr/Hf ratios in granitic zircons. Geochem. J., 44, 65-72.

Worral, F., Pearson, D. G. (2001): Water-rock interaction in an acidic mine discharge as indicated by rare earth element patterns. Geochim et Cosmochim 65, 3027-3040.

Xu, X-S,, Zhang, M., Zhu, K-Y., Chen, X-M., He, Z-Y. (2012): Reverse age zonation of zircon formed by metamictization and hydrothermal fluid leaching. Lithos 150, 256-267. 
Rare elements distribution and mineralization potentiality of pegmatites

توزيع العناصر النادرة واحتمالية التمعدنات فى البجماتيت الموجودة فى جرانيت جبل ابو سميوك ، شمال الصحراء الشرقية ، مصر

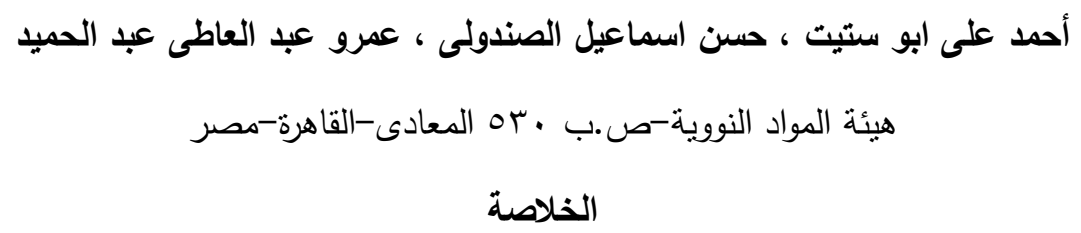

يهدف البحث الى دراسة توزيع العناصر النادرة واحتمالية التمعدنات للبجماتيت الموجودة فى جرانيت جبل ابو سميوك التى حئ تمتل جزء من جرانيتات جبل جتار بشمال الصحراء الثرقية ، مصر .

توجد البجماتيت على هيئة اجسام يترواح طولها ما بين امتار قلبلة الى م مثر و عرضها دائما ما يقل عن V متر ، باثكال مختلفة منها العدسى و الغير منتظم. تثير القياسات الاشعاعية ان بعض هذه البجماتيت بها شاذات اشعاعية حيث تم

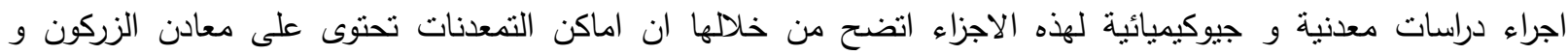
الفيرجزونايت و الكولمبيت و بعض الزينوتيم ويوجد بها أيضا تركيزات عالية من عناصر الزركونيوم و النيوبيوم والبورانيوم والثوريوم والعناصر الارضية النادرة. توجد هذه التمعنات بدرجات متفاوتة من متوسطة الى عالية داخل هذه البجماتيت. 